\title{
Is citizen journalism dead? An examination of recent developments in the field
}

\section{Bruce Mutsvairo}

Auburn University, USA

\section{Susana Salgado}

Universidade de Lisboa, Instituto de Ciências Sociais, Portugal

\begin{abstract}
The reliance on untrained reporters with limited or no understanding of journalistic standards has become increasingly widespread particularly in less democratic environments and these practices have impacted news gathering and reporting. There however has been some debate about the conceivability, capacity, reliability and acceptability of citizen journalists due to the lack of the professional standards associated with the profession. Even so, diverse forms of citizen journalism continue to emerge and develop in several countries in the Global South, such as Zimbabwe and Mozambique, examined in-depth in our study of the current frameworks, trends, practices and principles of citizen journalism in Africa. Buoyed by what appears like a slump in global citizen journalism research, we identify specific cases to rethink the concept, seeking to theoretically contribute to new directions on the phenomenon's role in African societies. Our analysis suggests that a reconceptualization of citizen journalism is imperative thanks to several factors, including improved access to the Internet and changing attitudes toward political dissent and participation, citizen journalism in Africa is taking new directions.
\end{abstract}

\section{Keywords}

Africa, Citizen journalism, Mozambique, participation, Zimbabwe

\footnotetext{
Corresponding author

Bruce Mutsvairo, Auburn University, School of Communication and Journalism, Tichenor Hall, Auburn, AL 36849-54I2, USA.

Email: bruce.mutsvairo@auburn.edu
} 


\section{Introduction}

Globally, empirical works on citizen journalism skyrocketed due to the widespread use of the Internet and digital devices, particularly from the early 2000s to around 2012, just after the 'Arab Spring' protests in the Middle East and North Africa. Since then, research on citizen journalism in the Global South has maintained a noticeable presence even though it has apparently nosedived elsewhere. For example, recent research on Asia found citizen journalism thriving in countries enjoying less media plurality, such as Vietnam, Malaysia and Indonesia (Zeng et al., 2019). A study by Zeng et al. (2019) on China demonstrates how messages shared by ordinary people on social media platform Weibo proved useful in contradicting and questioning the credibility of official Chinese media reports. Another study by Luo and Harrison (2019) concluded that interactions by citizens on Weibo were not only influencing policymaking, but also playing an agendasetting role for traditional media.

These recent studies draw attention to the fact that forms of citizen participation and reporting are notable for their impact on society in some countries, where thanks to restrictive media and freedom of expression laws, few would have imagined successful citizen reporting initiatives are being registered. In several African countries, citizen journalism also has social and political influence. Mpofu $(2013,2015,2016)$ has carried critical research that shows the power of citizen journalism in South Africa and Zimbabwe, while Sitoe (2017) has delved into the cases of Mozambique and Kenya to conclude that citizen journalism is mainly used for whistleblowing. Such research also illustrate how forms and objectives of citizen journalism are transformed in time and space. These developments thus provide an impetus to further studying citizen journalism through new perspectives and theoretical orientations.

Our approach looks into the recent developments of citizen journalism in Africa, paying particular attention to cases in which it has been considered central to both citizen participation and to the development of journalism (e.g. Mozambique and Zimbabwe). Our objective is to characterize the specific forms that citizen journalism has taken on the continent and discuss the reasons behind its enduring success at a time where in other parts of the world the interest has been declining. We are thus interested in mapping forms of citizen journalism on the African continent and in doing so, zooming in on the reasons behind its success in Mozambique and Zimbabwe. As shown later in the discussion section, over half percent of Zimbabwe's 12 million citizens enjoys Internet access, while Mozambique has over 6 million Internet users, about 20 percent of the population (Internet World Stats, 2020)

Our article is not an empirically-driven study. Instead, we use recent studies and developments in Africa to question the real uptake of citizen journalism with the intend to open up a discussion among journalism scholars on whether the lack of recent research on citizen journalism globally means that the phenomenon is also dying in practice. What 'new perspectives', to follow Zeng et al.'s (2019) lead, if any, are emerging in Africa? We believe it is important to revisit and reevaluate citizen journalism because at its peak, it led to a raft of research predictions across the continent including projections of its ability to act as an alternative public space as suggested by Mare's (2013) analysis of @Verdade in Mozambique or Ogola and Owuor's (2016: 299) assessment of the development of citizen 
journalism in Kenya in which they concluded that the participatory nature of citizen journalism allowed 'outsider voices in issues of national and community' matters.

We look at the most recent literature about citizen journalism to assess trends and pay special to the following research questions: how has citizen journalism developed in Africa? What forms of citizen journalism have emerged in Mozambique and Zimbabwe? These questions also provide the opportunity to discuss the concept and analyse the impact of different forms of citizen journalism.

\section{Nuances of citizen journalism in extant research}

Citizen journalism has been linked to prospects of democratization and to the transformation of mainstream journalism. Tshabangu (2019)'s $\mathrm{PhD}$ research revealed citizen journalism was flourishing in Zimbabwe leading not only to the generation of political narratives, but it was also creating counterhegemonic news frames. Citizen journalism was also pointed as a form of counteracting the credibility deficit in the dissemination of news in authoritarian environments (e.g. Dare, 2012; Sheen et al., 2020). In addition to its relevance as a journalism phenomenon and its close relation with digital dissidence for political change and overall democratization processes (Ali and Fahmy, 2013; Ananny and Kreiss, 2011; Salgado, 2012; Mapudzi and Osunkunle, 2017; Min, 2016), citizen journalism is believed to have a broad impact on civic participation (ArdèvolAbreu et al., 2018; Dare, 2012; Nah et al., 2017) and audience engagement (Chung et al., 2018), but also on de-professionalization (Loosen and Schmidt, 2012; Splichal and Dahlgren, 2016) and on the emergence of new models of newsmaking (Ostertag and Tuchman, 2012; Wall, 2018), including on photojournalism (Allan, 2017).

In recent times, very few studies have focused exclusively on the West. In this part of the world, the democratic potential of citizen journalism was highlighted by Bodrozic and Paulussen (2018) in their study of Mvslim, a Belgium-based citizen media platform. The authors concluded that citizen media had a role to play in covering issues that are not adequately represented in conventional media outlets, including minority groups. In their examination of another Belgium-based non profit citizen-oriented media, however, Wiard and Simonson (2018: 13) found that citizen journalism 'fosters weak participation'. Another study by Kus et al. (2017) focused on the importance of educating citizen journalists in the United Kingdom, Germany, Austria, Switzerland, Italy and Poland, concluding that the interviewed non-professionals saw little value in formal citizen media training. In Krajewski and Ekdale's analysis of citizen journalism in Haiti, a country the authors characterize as the 'as the poorest country in the Western Hemisphere', Krajewski and Ekdale (2017: 229) cautioned against glorifying citizen journalism, concluding that CNN's $i$ Report reproduced stereotypical narratives normally associated with traditional media in the coverage of poorer societies.

Among other examples of research on citizen journalism outside the African continent are those focused on China. Darbo and Skjerdal (2019) interviewed citizen journalists in Hong Kong, concluding that in their daily practices, they resist from being labelled 'non-professional' because, like professional journalists, reporting news truthfully and being fair forms part of their identity. In another study exploring the extent to which WeChat could be considered a platform for potential participatory journalism in China, 
$\mathrm{Wu}$ and Wall (2019) concluded that the mobile application played a pivotal role as an alternative source of news.

A number of factors could have contributed to the global decline in citizen journalism research and overall interest. These include the reluctance by some researchers (e.g. Grant, 2007; Keen, 2007) to consider citizen-based reporting as legitimate journalism, the fascination among civil society organizations to see journalism as empowerment (Berger, 2011) or as a democratizing tool (Mutsvairo and Ronning 2020; Mudhai 2013, Matsilele and Ruhanya 2020), even where little evidence is provided. These different views of citizen journalism's forms and functions in society ultimately affect the general perception of the phenomenon including what is considered citizen journalism, while several cases are disregarded because of their perceived lack of adherence to ethical standards in comparison to conventional journalism. Still, a number of studies have been assessing the role of citizen journalism in some African countries.

Banda (2010: 26) conducted one of the earliest continent-wide studies of citizen journalism in Africa defining the practice as 'a rapidly evolving form of journalism where common citizens take the initiative to report news or express views about happenings within their community'. In simpler terms, citizen journalists, consume but also use digital technologies to produce and share content. They are normally not trained as professional journalists, which perhaps explains why Charles and Allan (2019) have called them 'accidental journalists'. Ajao and Wielenga (2017) found citizen journalism critical in conflict-based reporting after examining the contribution of Kenya's Ushahidi citizen project in reporting violent acts during the country's 2008 elections. The same year, Zimbabwe also held a national election and Moyo (2009) analysed citizens' uses of SMS (Short Message Service) and weblogs to investigate the mediation potential of citizen journalism in a politically volatile environment and found evidence of citizen engagement but warned journalism values were at stake in an era where anyone could become a journalist. Despite these relevant studies, citizen journalism's different dimensions (including ethics), and the adaptation of the concept in African settings have not been sufficiently addressed in research. Studies in the Western settings have been used as points of departure for conceptual explorations of citizen journalism in Africa up until the new millennium when empirical analysis started creeping in. Additionally, citizen journalism in Africa is often mistaken with online citizen participation and the introduction of digital technologies in newsrooms (e.g. Mabweazara, 2015; Mabweazara et al., 2014; Mudhai, 2013).

Findings of a study on citizen-run, diasporic online platforms, established that the proliferation of citizen journalism was upsetting 'the elite and politically dominated public spheres' (Mpofu, 2014: 8). Attempting to study ethical patterns in an African networked sphere, Mutsvairo, Columbus and Leijendekker (2014) concluded that citizen journalists are driven by the desire to inform others choosing to reject censorship and governmental control. However self-promotion has been an important motivation in other cases (Salgado, 2012).

Other studies have questioned the assumption that citizen journalism strengthens African democratization due to pervasive inequalities in access to technology (Mutsvairo, 2016; Mabweazara, 2015). The importance of Internet literacy has often been underestimated when assessing the real impact technology and particularly citizen 
journalism could have. Moreover, not everyone with access to Internet understands its potential and what to use it for. Following this concern, Salgado (2014) outlines problems associated with the African digital divide in her analysis of the Internet's role in advancing democracy in the continent's Lusophone countries. Even when citizens actually have access to citizen journalism platforms, it is still unclear, how many are participating and to what effect.

\section{Citizen journalism: An 'all-inclusive package' or a broad concept?}

The infusion of citizen-gathered information into news programming has been changing the dynamics of journalism. No longer are traditional journalists the only ones gathering and telling the stories. With untrained actors joining the fray, journalism has entered a new era, dramatically transforming newsgathering and content-sharing patterns characterized and dominated by the explosion of audience-driven coverage, previously unseen. Realizing the potential of citizen journalism, several mainstream news outlets encourage members of the general public to freely participate online and offline directly introducing a new form of participatory media exchange: participatory news (Atton, 2009; Deuze et al., 2007; Singer, 2011). Forms of the citizen participation in newsgathering and news production have been called 'participatory publishing' (Nguyen, 2006), 'networked journalism' (Jarvis, 2006), 'guerrilla journalism' (Woo-Young, 2005); open source journalism (Bentley et al., 2005) or 'emancipatory journalism' (Kperogi, 2011: 326). Others like Hujanen and Pietikainen highlight the link between citizen journalism and interactivity, which they define as "the increasing opportunity to communicate across old boundaries of time and place, and between journalists and citizens"' (2004: 384), while according to Quandt (2011: 160), and thanks largely to its grassroots and participatory nature, citizen journalism is 'a form of communication by the public for the public'. But participatory journalism is however not limited to citizens only as conventional journalists practice it too (Lawrence et al., 2018; Wasserman and Garman 2012) and therefore although it might coincide occasionally with citizen journalism is not synonymous with it.

Citizen journalists have challenged the predominantly institutionalized form of news dissemination and several factors, including the ubiquity of new technologies, have coincided with the explosion of citizen journalism. Declines in newspaper circulation precipitated by drops in advertising (Krueger and Swatman, 2004) represent a shift in thinking that simultaneously drives citizen journalism. Facing a bleaker future, newspaper managers have had to rethink strategies and introduce models that appeal to a new generation of readers (Bakker, 2002). It could also be argued that citizen journalism has emerged as a direct response to continuous mergers and acquisitions within the media industry, which have globally led to the convergence of a few corporations setting the news agenda.

Nevertheless, not everyone is impressed by this emergent form of journalism. Take its professed lack of objectivity, for example. Traditional journalists are not willing to accept the citizen-inspired movement because they believe objectivity is central to and defines what is journalism (Lewis et al., 2010). Although the practice of citizen journalism often contributes to plurality and to the inclusion of voices otherwise excluded from the news, the 
impact of the lack of professionalization has been seen as strong disadvantage (Lindner et al., 2015).

Our approach starts with the notion that non-organized actors are playing a role in information gathering, multimediality and interactivity. Drawing from the African countries' experience with citizen journalism, we thus propose a rather broad conceptualization of citizen journalism based on the understanding that anyone with access to the Internet could produce and disseminate information digitally, potentially becoming a citizen journalist. Certainly, one could argue that a citizen that sporadically reports news and information, particularly if the content produced does not follow the ethics and professional standards of mainstream journalism (including verification) is actually a citizen journalist. However, given the changing media environments, in which there is now a plethora of new formats, genres and new actors, we posit that these forms of amateur news production should be considered as citizen journalism. In fact, this view is close to the initial sense of citizen journalism as the collection and dissemination of news and information by the general public. What has further blurred the boundaries of what is considered news and information is in fact technology, that is, the variety of formats enabled by the online platforms and applications.

African citizen journalism presents other important specificities and a great variety of formats. Unlike in other parts of the world, where the work of citizen journalists can mostly be found in an organized form, in some African countries, accessibility to Internet is allowing aspiring citizen reporters to gather, write, edit and share stories online, mostly in unorganized fashion, meaning some become citizen journalists even without knowing. Some of those gathering and disseminating news do not represent entities or organizations, but their contributions often impact on the news agenda and on the overall availability of diverse information (from different sources), boosting plurality even if this does not come with its own risks, such as the spread of false information, defamation, hate speech and other forms of inflammatory language (Salgado, 2012), which can then be used as justification for further control of the freedom of expression.

The option of choosing a broader conceptualization leads to accounts that are crossdisciplinary in nature. Take, for example, the attempts to show struggles faced by civic participants in online and offline African settings as examined by Banda (2010) or Obadare and Willems (2014). This broader approach, encouraged as journalism, normally carries practical implications within a given society or community. It should not thus be considered a standalone practice since it touches upon people's lives and its immediate dependence on technology means that any attempts to examine its role in a particular society should also scrutinize the economic, political and social implications thereof.

In fact, the potential impact of the Internet depends greatly on the socio-political context of a country (Salgado, 2014), and the same holds true for the impact of citizen journalism in a country or community (Salgado, 2015; Skjerdal, 2016); it is highly dependent of socio-economic factors, political openness and cultural norms. When and if the people are facing a catalogue of problems including starvation and disease, being online activists or journalists does not become their top priority. Besides, a person living in an authoritarian regime is perhaps less likely to participate in anti-government protests for fear of reprisals. Furthermore, it is also important to note that access to Internet does not 
translate into digital participation either. And even when that happens, participation is not always equitable to citizen journalism.

\section{Citizen journalism in Zimbabwe and Mozambique}

Citizen journalism seems to thrive in environments with constraints to freedom, but where technologies that enable alternative means of expression were rapidly embedded in society. Mozambique and Zimbabwe are two prime examples of this. Zimbabwe's media space has opened up considerably since the late President Robert Mugabe was removed from power in 2017 and a significant shift in terms of freedom of expression has been registered. Given that Mugabe's government did not tolerate dissent, since its ejection, several self-styled social media-based journalism entities have emerged (e.g. Zimbabwe Social Media News, which started operating on Facebook in February 2019 and has since amassed over 223,000 'likes', or Baba Jukwa with 134000 likes), while other notable journalists including award-winning Hopewell Chin' ono have used their social media platforms to openly confront the government over several allegations. Mutsvairo and Muneri (2019) conducted interviews with Zimbabwean journalists, who confirmed Zimbabwe had mildly open up since Mugabe lost power. Reporters Without Boarders has also declared 'access to information has improved and self-censorship has declined' (RWB, 2020).

However, some journalists have also been arrested leading to widespread cynicism among citizens with some suggesting there is little evidence of change in the 'new era' as most policies and laws introduced by Mugabe's government were still intact. Mozambique also shows some discrepancies between laws that ensure freedom in theory and practices of harassment and persecution of journalists and dissenters in general. After the peace agreement in 1992, which ended 16 years of civil war, the country has made some progress in political stability and freedom, but constraints to freedom of expression and to press freedom are still experienced occasionally.

\section{Zimbabwe}

Even though the gathering of news is still regulated by the state, the removal of Mugabe from power in November 2017 has left the country with several social media-based news outlets, which are openly operating, some without the required license. Still, it is a crime under Zimbabwean law to practice journalism without official accreditation, which leaves, for example, those filming and posting videos on social media platform YouTube potentially exposed. President Emmerson Mnagangwa's government insisted it was committed to repealing harsher media laws by August 2019 even though proposed replacements have also faced criticism from media rights organizations. The manifestation of citizen journalism in Zimbabwe was originally triggered by the availability and widespread use of smartphones and free Wi-Fi zones including the one provided by Internet service provider Zolspot, which is available across major cities.

Zimbabwe's citizen journalism space has for years been dominated mostly by antigovernment and civil society-funded initiatives. Funded by Netherlands-based media advocacy group Free Press Unlimited, which has been actively funding projects that 
promote citizen involvement in news gathering, Mobile Community Zimbabwe (MCZ) is one of such projects. Calling itself 'school of citizen journalism' (MCZ, 2020), it provides community reporting training and has an 'ethical policy and pledge to the audience' vowing to maintain standards, such as truthfulness and impartiality. The virtually-based training facility aims at 'empowering' young Zimbabweans so that they can 'contribute to the plurality and diversity of news' through mobile phone reporting initiatives. Stories published on its website as well as on its Facebook page are however outdated, going back to 2016 and 2017. Another grant-funded organization, the Media Centre, also runs workshop and training facilities for citizen journalists. Tipster is another foreign-funded citizen journalism initiative, which provided news reports between 2016 and 2018 before sinking into oblivion. Mainstream media players such as US-funded Studio 7 and United Kingdombased Zimeye have also been harnessing the power of citizens since the rise of citizen journalism in the early 2000 s, taking advantage of the pervasive smart phones use to let citizens tell stories from their own perspectives.

Not to be outdone are online community spheres Zvirikuitika muKwekwe (What is happening in Kwekwe), a citizen-centred Facebook page used by residents of the town of Kwekwe to generate and share community news. Launched in 2012, this Facebook page has attracted a combined online audience of up to 40,000 plus followers and there is no evidence that it is funded by foreign organizations or governments. While the number of 'likes' hardly represents each of the central gold mining town's 80,000 residents, the site is relatively known among Zimbabweans. Besides, it has been occasionally cited in the mainstream press. Anyone is free to join the online community by 'liking' the page. News and updates are openly shared by citizens in unprecedented fashion, providing current information and provoking debates on social and political issues.

Blogs have traditionally been run by Non-Governmental Organizations, especially during the Mugabe era as very few individuals were unwilling to run organized platforms especially those covering politically-sensitive news. In fact, a study by Moyo (2011) concluded that in spite of marked success, the political economy of blogging restricted it from having a real impact in Zimbabwe because its association with the liberal social movement doctrine left it entirely elitist and thus depending heavily on neoliberal funding.

Social media has, on the other hand, proven to be a useful platform especially for those willing to anonymously share information critically triggering the mass participation of citizens in online discussions and replacing the mainstream media when these do not cover an issue or an event, such as when President Mugabe fell to the ground at the main airport in Zimbabwe in early 2015. Since such a fall would have not been covered by the national press, the reporting role was hijacked by citizen journalists, a development that illustrates the role of citizen journalism in a country with a constrained democratic space. Social media also allowed citizens to report the dynamics of the Mugabe's otherwise highly secret foreign trips. Using website such as www.flightstats.com citizens could easily report on the whereabouts of their president through social media platforms. This was unprecedented as only the official press had traditionally been the lone reporter of such presidential foreign trips. Before Whatsapp, participants were restricted mostly to urban dwellers but using the cross-platform service, those living in remote areas 
directly engage with others as long as they can afford Internet access. The rapid exchange of information on Whatsapp has however led to increasing fears of the spread of 'fake news' or disinformation and propaganda. (Mutsvairo and Bebawi, 2019).

\section{Mozambique}

Contrary to Zimbabwe, the most significant cases of citizen journalism in Mozambique have been very close to mainstream news media, either made to resemble mainstream journalism or are actually linked to existing news media outlets, such as the successful efforts of newspaper@Verdade (in English The Truth) to involve citizens in the news gathering and reporting of information in their communities, or during special events, such as elections.

Mozambican citizens living in urban areas are used to some diversity in news sources and to alternative and independent news media initiatives. Before the Internet, several community radio stations and fax newspapers gave journalists and citizens the opportunity to express their views as well as to gather and spread information on sensitive issues bypassing the government control and the self-censorship, which is still rather common in state-owned media outlets. The Internet has allowed the further development of alternative media through the emergence of more news outlets and the possibility of distributing some of the existing outlets in new formats (emails, websites, newsletters, blogs, other social media, etc.). It has also boosted the motivation of different actors to participate in debates not only through these new news media outlets, but also through their own means of expression, such as blogs. While political authorities still try to control much of the media content that actuality reaches the majority of the population, more freedom has been tolerated in online news media because their reach is still limited, particularly when compared to the mainstream news media with wider audience levels.

Nevertheless, frequently online news media face credibility problems. They are often accused of unprofessionalism, amateurism, and of publishing rumours and information that has not been previously verified. The fact that some journalists in these media outlets do not have the proper training explains some of these accusations, but the critical positioning towards the authorities of some of them also fuels the criticisms. In addition, the economic difficulties of many news media outlets had already blurred the boundaries of the profession and stretched the limits of journalistic objectivity. Most news media outlets have very few resources, lack of professionalization and training of many journalists, which impacts on the actual news coverage that is usually made of facts and reality in general. It is not uncommon to see unverified reports being published as actual news; facts are often mixed with opinions and interpretations, which in turn are usually loaded with biased information, disinformation, as well as with gossip and slander.

As a result of these poorly-resourced newsrooms, some citizens are occasionally invited to provide reports and opinions through various news formats, however, as in most forms of citizen journalism, their independence is not assured; in fact, most times, they are selected because of their political preferences. Citizens from remote areas are also invited to send reports, especially when something important happens, because the most remote parts of the territory are still largely inaccessible for mainstream media 
outlets to cover. Therefore, as a result of human and economic resources constraints, the reliance on citizen journalists is somehow common in Mozambique. Some authors (e.g. Atton, 2009; Paterson, 2013) even argue that more than participatory forms of journalism, these are mainly forms of subsidizing under-resourced newsrooms.

Newspaper@Verdade often resorts to citizen journalists with the objective of expanding its sources of information and overall newsgathering capacity. This newspaper has always assumed a grassroots positioning, addressing the low-income communities in particular, and is known for being critical of the government and for encouraging the participation of readers in suggesting and in writing themselves news content. In addition, it has also launched an innovative experience during the 2009 presidential, legislative and provincial elections, when encouraged citizens to be reporters in their own neighbourhoods by sending their news stories to be published on a specific webpage of the newspaper's website (verdade.co.mz/eleicoes2009). This online resource included a directory list of the various inputs that were sent with the following information: report title, date, location and an indication of whether or not the report had been verified. The initiative allowed the newspaper to have different reporters in several locations during the campaign and as the voting occurred, making it possible, for instance, to know about incidents in different provinces and polling booths (Deutsche Welle, 2014; Salgado, $2014 ; 2015)$. These initiatives were reproduced in the following elections.

When in 2008, 2010 and 2012, there were violent popular demonstrations in some of the country's main cities against the rising cost of living, @Verdade also used the Internet and the citizens' willingness to participate actively in the news production processes to report on the crises. In 2010, it uploaded and posted many articles and videos on its website and Facebook page, and integrated an Ushahidi crisis report tool on its website. During the cyclical rainy or drought seasons, citizens are also requested to report on the situation in their villages.

Because@Verdade does not have the resources to cover all newsworthy events throughout the territory and in the case of elections cannot send journalists to every polling station in the country to monitor the voting process, it thus often relies on its community of engaged readers. The functioning is simple: the newspaper's readers send their comments, observations, photos and videos and the @Verdade's editors monitor those inputs, verify and publish the most newsworthy reports, and in some cases, when resources allow, even assign journalists to follow-up the information previously given by citizens. The newspaper has also maintained a 'Cidadão Repórter' (Citizen Journalist) space on its website, to publish citizen reports, but this space has not been regularly updated in recent years and most activity seems to have moved to a new website, Forum @ Verdade. Newspaper @Verdade has thus been encouraging readers to exercise their rights as citizens by complaining about problems and sending reports on what happens in their streets, neighbourhoods and cities, via Internet or SMS. Such citizen participation often takes the form of citizen journalism, particularly when the main objective is also related to the monitoring the political decision-making processes, by enhancing transparency and exposing corruption. 


\section{Discussion: Using case studies to improve concept clarification}

The analysis of these two cases shows that Internet accessibility is largely concentrated on urban dwellers as the lack of infrastructure is still hampering the development and progression of broadband wireless Internet in many parts of Africa. Even worse, not everyone fully understands what is published and disseminated on the Internet and social media and its implications (Salgado, 2014). If journalism's role in society 'is to provide citizens with the information they need to be free and self-governing' (Kovach and Rosenthiel, 2007: 12), then recipients need to understand the meaning of what is being disseminated and need to have access and know how to work with technology if they want to engage in citizen journalism practices. Clearly not everyone has the same conditions. The costs for Internet accessibility are high for the majority of the citizens. For example, the cost of 1 Gigabyte in Zimbabwe, a country with an estimated 80 percent unemployed rate (Mutasa, 2016), is approximately USD75, the most expensive in the world. In Mozambique, the monthly cost of Internet is approximately USD45, which is more than half the national minimum wage, according to the A4AI (Alliance for Affordable Internet, 2018). These prices are too expensive and provide indirect evidence that citizen journalism is not being practiced by every individual in Zimbabwe or Mozambique. Nevertheless, there have been important developments. The increased availability of Internet has facilitated citizen participation in online debates and has propelled cases of citizen journalism and different forms of citizen journalism have been manifesting.

Knowledge exchange and interaction are only possible when more people are technologically connected. Several factors are instrumental in determining practices of citizen journalism in Africa and in Zimbabwe and Mozambique in particular. In Zimbabwe, more than half of the country's 16 million citizens have access to mobile Internet (Gambanga, 2016) and in Mozambique, Internet access is also available in urban centres and major cities. Even though Mozambique was one of the countries with less Internet penetration in 2015 , only $5.9 \%$ ( $0.5 \%$ of the users in Africa), in June 2019 , this percentage grew to $20.8 \%$. In Zimbabwe, in 2015 , the numbers were $47.5 \%$ (2.0\% of users in Africa) and in June 2019 the Internet penetration level was 48.6\% (Internet World Stats, 2015, 2019).

Our analysis questions the socio-political online-offline matrix created by the citizenoriented online publications. Even though the online environment allows for some freedom, which otherwise is not available offline, there are still constraints including self-censorship of political-related content. In Zimbabwe, those critical of the government on social media networks have been arrested even though it is important to highlight that, in most cases, they have been freed by courts. The Zimbabwean government has also been looking at ways to block content using Chinese-made technologies. In Mozambique, although the Internet and in some cases the social media have been used to criticize the governments' decisions, finding ways to control directly access and contents has not been a priority to governments due to the low penetration of the Internet and of social media in the country as of yet. 
In Zimbabwe and Mozambique, platforms for the distribution of content are becoming available as more and more citizens actively embrace digital technologies. However, a discussion on what constitutes citizen journalism is something that requires further attention. In restrictive environments like Zimbabwe and Mozambique, information that otherwise would have not been openly shared by the government and mainstream news media is often associated with citizen journalism. In Zimbabwe, citizen journalism takes a dissident form often encouraged or supported by the civil society. Thus citizens sharing information on Facebook or Whatsapp may not call themselves 'citizen journalists' but organizations that support such initiatives like Free Press Unlimited will do so. In Mozambique, even though there are occasionally other forms of citizen journalism, spontaneous and unorganized, the most important initiatives are organized by mainstream news media.

Although citizen journalism has been playing an important role in both Mozambique and Zimbabwe, these two cases are substantially different in terms of how citizens report and contribute to non-official journalism. While the Mozambican case is communitycentred and shows a more organized trend of citizen journalism, the Zimbabwean case also has a few examples of community engagements, but it mainly illustrates a different scenario in that its citizen journalistic trends are more fragmented and less organized, and when they are organized, they are built on, supported or funded by civil society organizations and NGOs, which more or less makes them anti-government in nature. Additionally, Zimbabwean news produced by citizen journalism mostly cover politics, whereas Mozambican reports cover a wide range of areas.

There are also key challenges related to ethics and good practices. Verifying whether people use fake or real names on these platforms is a difficult task. Many participants still choose to remain anonymous due to constraints to freedom of speech in both countries. However, once citizen journalists choose to remain anonymous, concerns are raised regarding the accuracy and believability of their accounts. This is in line with the need to respect normative principles of journalism as suggested by Zhang and Cameron (2003), who argue that anonymity could lead to journalistic manipulation. Audiences consider articles with anonymous sources less credible (Sternadori and Thorson, 2009). Thus, truth-telling especially in the social media era fosters trust between the producers and recipients of news.

While in Zimbabwe citizen journalists usually show great disregard of normative journalism standards, in Mozambique, although anonymity is also an issue that undermines trust in online and alternative sources of information, most important citizen journalism initiatives are framed and integrated in a traditional journalistic environment. This ensures that these citizen journalists follow many of the guidelines of the journalistic profession, such as verifying the information provided and some of the professional ethics standards. There is in fact a concern with posting information that has been carefully checked to avoid that the @Verdade online website is used to publish gossip and rumours. Adherence to journalistic principles brings credibility to the work of Mozambican citizen journalists while fearing political persecution and in a notable departure from the past. Even though it is not without risks, the liberation associated to citizen journalism practices in Zimbabwe is also pushing both citizen participation and journalism further. 
This analysis clearly demonstrates the need to discuss what is citizen journalism today and to rethink the real meaning of news in an Internet and social media era. For example, while news articles produced by newspapers in and outside Zimbabwe are shared on 'What's Happening in Kwekwe', this Facebook page also attracts a sizeable amount of memes, images, cartoons and jokes that essentially may not be considered key information for citizens, which is an important requisite in defining what constitutes news (Shaw, 2009; Mutsvairo, 2019). But would this be considered 'news' in the sense that Harcup and O'Neill (2017: 1482) characterize and define news? These authors suggest a revised and updated set of contemporary news values that take into account the influence of social media in determining what constitutes news. One of their proposals is to include in the news value criteria list 'shareability', namely 'stories that are thought to likely generate sharing and comments' via social media. Whether a meme, for instance, meets the news characterization requirements is open to debate and its actual content may influence the conclusion, but someone living in a controlled freedom environment does understand the information potential of all of these different types of content. Citizen journalism has therefore been transforming the conventional understanding of news, which used to be focused on gathering and distributing reliable and verifiable facts. On social media, the role of gatekeepers, such as journalists and editors, is non-existent as citizens share freely all kinds of content, including information, even if not verified or entirely reliable. Then, much of this content is actually treated as news in these contexts and is transferable and translatable to offline realities. This often happens in Mozambique where the information gathered by citizens is part of the traditional news offering as many issues raised by citizen journalists are included on the agenda, where they become topics of public discussion. In Zimbabwe, while active online participation is certainly encouraging, the links are more noticeable in the citizens' use of newfound information to question officials and push for political change.

In a manner very similar to what McLuhan (1995) suggested with the medium being the message, meaning that it is the medium itself that shapes and controls human interaction, Internet and social media are transforming communication and information in Mozambique and Zimbabwe. They are changing the behaviours of citizens as they become more interactive, and thus pushing forward democracy and journalism. Interests in participation are being driven by the ubiquity of smart phones disseminated by new technologies even more than by the message that these gadgets carry. Thus while citizen journalism initiatives manifest very differently in Africa, they have nevertheless become forms of political participation and engagement in new democracies, where freedom of expression is still limited by governments. In Mozambique, despite the economic difficulties of both media organizations and citizens, citizen journalism is in some cases being used to overcome the lack of reporters in remote locations, but this also means giving voice to more citizens, who have the opportunity to see their real problems debated and included in the agenda.

In conclusion, a study of this magnitude would not be complete without limitations. For instance, further empirical research would need to be conducted to reinforce our analysis of these two cases. We have shown the complexity of the concept of citizen journalism, which is fundamentally problematic because it touches freedom of expression, participation and journalistic work practices equally. Our approach has shown 
different uses and practices of citizen journalism in two neighbouring southern African countries. Current circumstances in Mozambique and Zimbabwe determine ways through which citizens are embracing digital technologies and engaging in citizen journalism practices. Citizen journalism is giving a voice to citizens in Africa to record their concerns with authorities, forcing in some cases, governments to be responsible to their citizens, inevitably providing an all-important platform for public debate and plural information. In-depth research focused on other African countries would be key in showcasing the variety of forms of citizen journalism and the motivations behind the involvement of citizens in such practices. This knowledge would further advance our understanding of citizen journalism and of its real impact on politics and society.

\section{Funding}

The author(s) received no financial support for the research, authorship, and/or publication of this article.

\section{ORCID iD}

Bruce Mutsvairo (iD https://orcid.org/0000-0001-7520-9739

\section{References}

Ajao T and Wielenga C (2017) Citizen journalism and conflict transformation: The Ushahidi's Response to Kenya's 2008 Post-Election Violence. Matatu Journal for African Culture and Society 49(2): 467-486.

Ali SR and Fahmy S (2013) Gatekeeping and citizen journalism: The use of social media during the recent uprisings in Iran, Egypt, and Libya. Media, War \& Conflict 6(1): 55-69.

Allan S (ed.) (2017) Photojournalism and Citizen Journalism: Co-operation, Collaboration and Connectivity. Oxon and New York: Routledge.

Alliance for Affordable Internet (2018) Affordability Report - Mozambique. Available at: https:// a4ai.org/affordability-report/ (accessed August 2019).

Ananny M and Kreiss D (2011) A new contract for the press: Copyright, public domain journalism, and self-governance in a digital age. Critical Studies in Media Communication 28(4): 314-333.

Ardèvol-Abreu A, Hooker CM and de Zúñiga HG (2018) Online news creation, trust in the media, and political participation: Direct and moderating effects over time. Journalism 19(5): 611-631.

Atton C (2009) Alternative and citizen journalism. In: Wahl-Jorgensen K and Hanitzsch T (eds) Handbook of Journalism Studies. New York and London: Routledge, pp. 265-278.

Banda F (2010) Citizen Journalism \& Democracy in Africa: An Exploratory Study. Grahamstown: Highway Africa.

Bakker P (2002) Free daily newspapers; business models and strategies. JMM the International Journal on Media Management 4(3): 180-187.

Berger G (2011) Empowering the youth as citizen journalists: A South African experience. Journalism 12(6): 708-726.

Bentley C, Littau J, Hamman B, et al. (2005) The citizen journalism movement: MyMissourian as a case study. Paper presented at the annual convention of the Association for Education in Journalism and Mass Communication, San Antonio, TX, 1-4 August.

Bodrozic S and Paulussen S (2018) Citizen media practices at the digital startup mvslim. Journalism Practice 12(8): 1061-1069. 
Charles M and Allan S (2019) Citizen Journalism. In: Vos V and Hanusch F (eds) The International Encyclopedia of Journalism Studies. Mahwah, NJ: John Wiley \& Sons.

Chung DS, Nah S and Yamamoto M (2018) Conceptualizing citizen journalism: US news editors' views. Journalism 19(12): 1694-1712.

Dare S (2012) The rise of citizen journalism in Nigeria - A case study of Sahara reporters. Reuters Institute Fellowship Paper, University of Oxford, Oxford. Available at: https://reutersinstitute.politics.ox.ac.uk/sites/default/files/2018-01/The $\% 20$ Rise $\% 20$ of $\% 20$ Citizen $\% 20$ Journalism $\% 20$ in $\% 20$ Nigeria $\% 20-\% 20$ A $\% 20$ Case $\% 20$ Study $\% 20$ of $\% 20$ Sahara $\% 20$ Reporters.pdf

Darbo KN and Skjerdal T (2019) Blurred boundaries: Citizens journalists versus conventional journalists in Hong Kong. Global Media and China 4(1): 111-124.

Deutsche Welle (2014) “Cidadão repórter" é o segredo do sucesso do jornal moçambicano @ Verdade. Interview with Adérito Caldeira. Available at: https://www.dw.com/pt-002/ cidadão-repórter-é-o-segredo-do-sucesso-do-jornal-moçambicano-verdade/a-17747569 (accessed August 2019).

Deuze M, Bruns A and Neuberger C (2007) Preparing for an age of participatorynews. Journalism Practice 1(3): 322-338.

Gambanga N (2016) Latest POTRAZ report shows an increase in Zimbabwe's mobile and internet penetration. Available at: http://www.techzim.co.zw/2016/03/latest-potraz-reportshows-increase-zimbabwes-mobile-internet-penetration/?relatedposts_hit=1\&relatedposts origin $=1863400 \&$ relatedposts position $=1 \#$.WBSFvRSFDFI

Grant S (2007) We Are All Journalists Now. New York: Focal Press.

Harcup T and O'Neill D (2017) What is News? News values revisited (again). Journalism Studies 18(12): 1470-1488.

Internet World Stats (2020) Usage and population statistics. Available at: https://www.internetworldstats.com

Internet World Stats $(2015,2019)$ Usage and population statistics. Africa Stats. Available at: https://www.internetworldstats.com/stats $1 . h t m$

Jarvis J (2006) Networked journalism. Available at: http://www.buzzmachine.com/2006/07/05/ networked-journalism

Keen A (2007) The Cult of the Amateur: How Today's Internet is Killing Our Culture and Assaulting Our Economy. Britain: Nicholas Brealey Publishing.

Kovach B and Rosenstiel T (2007) The Elements of Journalism: What Newspeople Should Know and the Public Should Expect. New York: Three Rivers Press.

Kperogi F (2011) Cooperation with the corporation? CNN and the hegemonic cooptation of citizen journalism through iReport.com. New Media \& Society 13(2): 314-329.

Krajewski JMT and Ekdale B (2017) Constructing cholera: CNN iReport, the Haitian cholera epidemic, and the limits of citizen journalism. Journalism Practice 11(2-3): 229-246.

Krueger CC and Swatman P (2004) Developing e-business models in practice: The case of the regional online newspaper. International Journal of Information Technology and Management 3(2-4): 157-172.

Kus M, Eberwein T, Porlezza C, et al. (2017) Training or improvisation? Citizen journalists and their educational backgrounds-A comparative view. Journalism Practice 11(2-3): 355-372.

Lawrence RG, Radcliffe D and Schmidt TR (2018) Practicing engagement: Participatory journalism in the Web 2.0 era. Journalism Practice 12(10): 1220-1240.

Lewis S, Kaufhold K and Lasorsa DL (2010) Thinking about citizen journalism: The philosophical and practical challenges of user-generated content for community newspapers. Journalism Practice 4(2): 163-179.

Lindner AM, Connell E and Meyer E (2015) Professional journalists in 'citizen' journalism. Information, Communication \& Society 18(5): 553-568. 
Loosen W and Schmidt JH (2012) (Re-)discovering the audience: The relationship between journalism and audience in networked digital media. Information, Communication \& Society 15(6): 867-887.

Luo Y and Harrison TM (2019) How citizen journalists impact the agendas of traditional media and the government policymaking process in China. Global Media and China 4(1): 72-93.

Mabweazara HM, Mudhai OF and Whittaker J (eds) (2014) Online Journalism in Africa: Trends, Practices and Emerging Cultures. London: Routledge.

Mabweazara HM (ed.) (2015) Digital Technologies and the Evolving African Newsroom: Towards an African Digital Journalism Epistemology. London: Routledge.

Matsilele T and Ruhanya P (2020) Social media dissidence and activist resistance in Zimbabwe. Media, Culture \& Society: 1-14. Available at: https://doi.org/10.1177/0163443720957886

Mapudzi H and Osunkunle O (2017) Citizen journalism as a contestant in the history of journalism. Communicatio 43(1): 17-36.

Mare A (2013) New media technologies and internal newsroom creativity in Mozambique: The case of @verdade. Digital Journalism 2(1): 12-28.

McLuhan M (1995) Understanding Media: The Extensions of Man. Cambridge, Mass: MIT Press.

Min S-J (2016) Conversation through journalism: Searching for organizing principles of public and citizen journalism. Journalism 17(5): 567-582.

Mobile Community Zimbabwe (MCZ) (2020) Available at: http://mobilecommunityzim.com/

Moyo D (2009) Citizen journalism and the parallel market of information in Zimbabwe's 2008 election. Journalism Studies. 10(4): 551-567.

Moyo L (2011) Blogging down a dictatorship: Human rights, citizen journalists and the right to communicate in Zimbabwe. Journalism: Theory, Practice and Criticism 12(6): 745-760.

Mpofu S (2015) When the subaltern speaks: Citizen journalism and genocide 'victims' voices online. African Journalism Studies. 36(4): 82-101.

Mpofu S (2014) Memory, national identity, and freedom of expression in the information age: Discussing the taboo in the Zimbabwean public sphere. In: Solo AMG (ed.) Handbook of Research on Political Activism in the Information Age. Hershey, PA: IGI Global, pp. 114128.

Mpofu S (2013) The power of citizen journalism in Zimbabwe. International Migration. 38(5): $41-57$.

Mpofu S (2016) Participation, citizen journalism and the contestations of identity and national symbols: A case of Zimbabwe's national heroes and the Heroes' Acre. African Journalism Studies 37(3): 85-106.

Mudhai OF (2013) Civic Engagement, Digital Networks and Political Reform in Africa. Basingstoke: Palgrave Macmillan.

Mutasa H (2016) Zimbabwe fails to curb escalating unemployment crisis. Available at: http:// www.aljazeera.com/news/2015/10/zimbabwe-unemployment-151017182157938.html (accessed 25 October 2016).

Mutsvairo B (ed.) (2016) Perspectives on Participatory Politics and Citizen Journalism in a Networked Africa: A Connected Continent. London: Palgrave Macmillan.

Mutsvairo B and Muneri C (2019) Journalism, Democracy and Human Rights in Zimbabwe. Lenham, Maryland: Rowman \& Littlefield Publishing Group.

Mutsvairo B (2019) Challenges facing the development of data journalism in non-Western societies. Digital Journalism 7(8): 1-6.

Mutsvairo B and Ronning H (2020) The Janus face of social media and democracy? Reflections on Africa. Media, Culture \& Society 42(3): 317-328.

Mutsvairo B, Columbus S and Leijendekker I (2014) Reconnoitering the role of (citizen) journalism ethics in the emerging networked public sphere. African Journalism Studies 35(3): 3-22. 
Mutsvairo B and Bebawi S (2019) Journalism educators, regulatory realities and pedagogical predicaments of the "fake news" era. A comparative perspective on the Middle East and Africa. Journalism and Mass Communication Educator 74(2): 1-15.

Nah S, Namkoong K, Record R, et al. (2017) Citizen journalism practice increases civic participation. Newspaper Research Journal 38(1): 62-78.

Nguyen A (2006) Journalism in the wake of participatory publishing. Australian Journalism Review 28(1): 143-156.

Obadare E and Willems W (eds) (2014) Civic Agency in Africa: Arts of Resistance in the 21st Century. Martlesham, Suffolk: James Currey.

Ogola G and Owuor M (2016) Citizen journalism in Kenya as a contested "Third Space". In: Mutsvairo B (ed.) Participatory Politics and Citizen Journalism in a Networked Africa. London: Palgrave.

Ostertag SF and Tuchman G (2012) When innovation meets legacy. Citizen journalists, ink reporters and television news. Information, Communication \& Society 15(6): 909-931.

Paterson C (2013) Journalism and social media in the African context. Ecquid Novi: African Journalism Studies 34(1): 1-6.

Pain P (2018) Educate. Empower. Revolt: Framing citizen journalism as a creator of social movements. Journalism Practice 12(7): 799-816.

Quandt T (2011) Understanding a new phenomenon: The significance of participatory journalism. In: Singer J, Hermida A, Domingo D, et al. (eds) Participatory Journalism: Guarding Open Gates at Online Newspapers. West Sussex: Wiley-Blackwell, pp. 155-176.

Reporters Without Boarders (2020) Zimbabwe. Available at: https://rsf.org/en/zimbabwe

Salgado S (2012) The web in African countries: exploring the possible influences of the Internet in the democratization processes. Information, Communication \& Society 15(9): 1373-1389.

Salgado S (2014) The Internet and Democracy Building in Lusophone African Countries. London $\&$ New York: Routledge.

Salgado S (2015) Political participation, alternative media and citizen journalism in lusophone Africa. In: Mutsvairo B (ed.) Participatory Politics and Citizen Journalism in a Networked Africa. A Connected Continent. London, UK: Palgrave Macmillan, pp. 187-201.

Sheen GC-H, Tung HH and Wu W-C (2020) Citizen journalism and credibility of authoritarian government in risk communication regarding the 2020 COVID-19 outbreak: A survey experiment. Working Paper. Available at: https://nyuad.nyu.edu/content/dam/nyuad/academics/ divisions/social-science/working-papers/2020/0040.pdf?fbclid=IwAR341Q83PAW2x6by7 IP1ST7NZIvEFBb3NuViPUS4uEy35eqH1E63YmdAmnMhttps://nyuad.nyu.edu/content/ dam/nyuad/academics/divisions/social-science/working-papers/2020/0040.pdf?fbclid=IwA R341Q83PAW2x6by7IP1ST7NZIvEFBb3NuViPUS4uEy35eqH1E63YmdAmnM\%3E

Singer J, Domingo D, Heinonen A, et al. (2011) (eds) Participatory Journalism: Guarding Open Gates at Online Newspapers. West Sussex: Wiley-Blackwell.

Sitoe MA (2017) O Jornalismo Cidadão em Moçambique e no Kenya: Análise comparativa dosWebsites@Verdade e Olho do Cidadão \& Kenya Monitor e Mzalendo. Novas Edições Acadêmicas.

Shaw IS (2009) Towards an African journalism model: A critical historical perspective. International Communication Gazette 71(6): 491-510.

Skjerdal T (2016)Why the Arab Spring never came to Ethiopia. In: Mutsvairo B (ed.) Participatory Politics and Citizen Journalism in a Networked Africa. London: Palgrave, pp. 77-89.

Splichal S and Dahlgren P (2016) Journalism between de-professionalisation and democratisation. European Journal of Communication 31(1): 5-18.

Sternadori MM and Thorson E (2009) Anonymous sources harm credibility of all stories. Newspaper Research Journal 30(4): 54-66. 
Tshabangu T (2019) Citizen journalism and alternative media in Zimbabwe: An ethnographic study of citizen participation, newsmaking practices and discourses at AMH Voices. Unpublished PhD Thesis, Stellenbosch University, Stellenbosch.

Wall M (2018) Citizen Journalism: Practices, Propaganda, Pedagogy. Oxon and New York: Routledge.

Wasserman H and Garman A (2012) Speaking out as citizens: Voice and agency in post-apartheid South African media. Communitas 17: 39-58.

Wiard V and Simonson M (2018) 'The city is ours, so let's talk about it': Constructing a citizen media initiative in Brussels. Journalism 20(4): 617-631.

Woo-Young C (2005) Online civic participation, and political empowerment: Online media and public opinion formation in Korea. Media Culture Society 27(6): 925-935.

$\mathrm{Wu}$ Y and Wall M (2019) Prosumers in a digital multiverse: An investigation of how WeChat is affecting Chinese citizen journalism. Global Media and China 4(1): 36-51.

Zhang J and Cameron GT (2003) Study finds sourcing patterns in Wen Ho Lee coverage. Newspaper Research Journal 24(4): 88-101.

Zeng X, Jain S, Nguyen A, et al. (2019) New perspectives on citizen journalism. Global Media and China 4(1): 3-12.

Zeng J, Burgess J and Bruns A (2019) Is citizen journalism better than professional journalism for factchecking rumours in China? How Weibo users verified information following the 2015 Tianjin blasts. Global Media and China 4(1): 13-35.

\section{Author Biography}

Bruce Mutsvairo is a Professor of Journalism at Auburn University in the US and a visiting Research Fellow at the Unit for Institutional Change and Social Justice, University of Free State, South Africa. His research sits at the intersection of journalism, democracy and human rights with a particular focus on the Global South.

Susana Salgado is a research fellow at the Institute of Social Sciences, University of Lisbon. Her main areas of research include political communication, democratization, and disinformation. She is currently PI of research project Hate funded by the Portuguese Foundation for Science and Technology (PTDC/CPO-CPO/28495/2017). 